\title{
Rate of fall of blood glucose and physiological responses of counterregulatory hormones, clinical symptoms and cognitive function to hypoglycaemia in Type I diabetes mellitus in the postprandial state
}

\author{
C.G. Fanelli, S. Pampanelli, F. Porcellati, L. Bartocci, L. Scionti, P. Rossetti, G.B. Bolli \\ University of Perugia, Department of Internal Medicine, Perugia, Italy
}

\begin{abstract}
Aims/hypothesis. The aim of this study was to establish the effect of a rate of decreasing plasma glucose concentrations on responses to hypoglycaemia, i.e. release of counterregulatory hormones, perception of symptoms, deterioration of cognitive function, and rates of forearm noradrenaline spillover, in the postprandial condition and in the sitting position.

Methods. We studied 11 subjects with Type I (insulindependent) diabetes mellitus, twice during clamped insulin-induced hypoglycaemia $(2.4 \mathrm{mmol} / \mathrm{l})$ after eating in the sitting position. On one occasion, plasma glucose was decreased at the rate of $0.1 \pm 0.003 \mathrm{mmol}$. $\min ^{-1} \cdot 1^{-1}$ (fast fall), on the other at the rate of $0.03 \pm 0.001 \mathrm{mmol} \cdot \mathrm{min}^{-1} \cdot \mathrm{l}^{-1}$ (slow fall). Subjects underwent a control euglycaemic clamp study as well.

Results. In response to fast-fall as compared to slowfall hypoglycaemia, which was about 30 min longer, cognitive tasks were performed as follows: TrailMaking B, PASAT 2 s, Digit Vigilance Test and Ver-
\end{abstract}

bal Memory deteriorated more, adrenaline increased less (2.8 \pm 0.5 vs $3.5 \pm 0.7 \mathrm{nmol} / 1, p=0.03)$, forearm noradrenaline spillover was greater $(6.5 \pm 1.0$ vs $\left.5.2 \pm 0.4 \mathrm{pmol} \cdot \mathrm{min}^{-1} \cdot 100 \mathrm{ml}^{-1}, p=0.04\right)$, and symptoms were no different. After recovery from hypoglycaemia, cognitive function was still deteriorated compared to the baseline with no difference between fast and slow-fall hypoglycaemia. The evident response of glucagon to postprandial hypoglycaemia contrasted with the blunted or absent response in the fasting state.

Conclusion/interpretation. In the postprandial condition and sitting position, fast-fall hypoglycaemia is more dangerous than slow-fall, because it deteriorates cognitive function more, and activates responses of counterregulatory hormones less than slow-fall hypoglycaemia. [Diabetologia (2003) 46:53-64]

Keywords Type I diabetes mellitus, postprandial hypoglycaemia, glucose counterregulation, cognitive dysfunction, forearm noradrenaline spillover.
When patients with Type I (insulin-dependent) diabetes mellitus experience hypoglycaemia after a subcutaneous (s.c.) injection of rapid-acting insulin at mealtime, blood glucose decreases to below normal concentrations at rates which can differ on different occasions. Among several factors, the injection of a rapid-

Received: 10 April 2002 / Accepted: 29 August 2002

Published online: 9 November 2002

C) Springer-Verlag 2002

Corresponding author: G. B. Bolli, University of Perugia, Department of Internal Medicine, Via E. Dal Pozzo, 06126 Perugia, Italy, E-mail: gbolli@unipg.it; e-mail: gbolli@libero.it

Abbreviations: CHO Carbohydrate acting insulin analogue as compared to human regular insulin, the technique of s.c. injection, insulin sensitivity and meal size and composition, are usually considered the most important determinants of the rate of decreasing postprandial blood glucose concentrations. After s.c. injection of rapid-acting insulin analogues [1], the rate of decreasing blood glucose is greater than after injecting human regular insulin [2, 3]. Therefore, it is expected that when hypoglycaemia is induced by mealtime administration of rapid-acting insulin analogue, the rate of decreasing blood glucose is greater than after injecting human regular insulin. In theory, different rates of decreasing blood glucose in the postprandial condition might result in different re- 
sponses to hypoglycaemia in terms of release of counterregulatory hormones, of generation of autonomic and neuroglycopenic symptoms, as well as of deterioration of cognitive function.

A number of studies in healthy, non-diabetic subjects and in patients with Type I diabetes [4, 5, 6, 7], dealt with these phenomena in the post-absorptive state and concluded that the rate of decreasing blood glucose affects neither counterregulatory hormone secretion, nor generation of symptoms in response to insulin-induced hypoglycaemia, nor cognitive function. Therefore, so far the nadir of blood glucose concentration achieved is regarded the main factor controlling the magnitude of responses to hypoglycaemia. Nevertheless, in a recent study in healthy, non-diabetic subjects, induction of hypoglycaemia at a very fast rate of fall, resulted in a hierarchy of responses different from that of historical studies with a slow rate of decreasing blood glucose concentrations [8]. Specifically, cognitive dysfunction preceded detection of counterregulatory hormone responses and the emergence of symptoms [8].

All previous studies examining the rate of decreasing blood glucose concentrations on responses to hypoglycaemia $[4,5,6,7,8]$ have been carried out in the post-absorptive condition and in the lying position. However, in the daily life of patients with Type I diabetes, hypoglycaemia could occur in the postprandial condition, particularly when the insulin dose is inappropriately high for the carbohydrate content of the meal. After a s.c. injection of rapid-acting insulin analogue, hypoglycaemia is expected to occur earlier than with human regular insulin $[9,10]$. In addition, in the postprandial phase, people generally either sit or stand. Posture affects responses to hypoglycaemia [11, 12]. In theory, it is possible that the rate of decreasing blood glucose in the postprandial condition and in the sitting position, exerts effects on responses to hypoglycaemia which differ from those obtained in patients fasting and lying in bed $[4,5,6$, $7,8]$.

The aim of our studies was to assess whether the rate of decreasing blood glucose concentrations to hypoglycaemia in the postprandial condition and sitting position, affects counterregulatory hormone, symptom and haemodynamic responses, as well as cognitive function in patients with Type I diabetes. In addition, we examined whether these responses normalize differently after the recovery of normal blood glucose concentrations. We designed an initial series of studies to establish the rate of decreasing postprandial blood glucose concentrations to hypoglycaemia in the clinical situation of patients with Type I diabetes. Thereafter, subjects were studied in a model of clamped postprandial hypoglycaemia induced by rates of decreasing plasma glucose concentrations closely mimicking those of the clinical situation.

\section{Methods}

Subjects. Institutional Review Board approval was obtained for these studies and all diabetic patients in the study gave their informed consent. Eleven subjects with Type I diabetes on longterm intensive insulin treatment [10] [six men, age 29 \pm 2.4 years, diabetes duration $12 \pm 2.7$ years, BMI $21.8 \pm 0.7\left(\mathrm{kgim}^{2}\right)^{-1}$, $\mathrm{HbA}_{1 \mathrm{c}} 6.6 \pm 0.3 \%$ ] were recruited among those attending the outpatient Diabetes Clinic of the Department of Internal Medicine (Di.M.I.), University of Perugia. At the time of the study, all Type I diabetic patients were free of any detectable microangiopathic complication, and were negative at the screening for autonomic neuropathy, as judged on the basis of a standard battery of cardiovascular tests [13].

Effects of s.c. injection of human regular insulin and the rapidacting insulin analogue lispro on the rate of decreasing postprandial plasma glucose concentrations. Of the 11 Type I diabetic subjects 5 were studied on four different occasions to establish the rate of decreasing plasma glucose concentration after s.c. injection of either human regular or rapid-acting insulin analogue lispro in the postprandial condition after meals with different carbohydrate content. Subjects were studied at 1- to 2 -week intervals in random order. On the day before the studies, patients had their usual insulin treatment with the last s.c. NPH insulin injection at 23:00 h. On the morning of the studies, patients had their usual s.c. lispro insulin injection at breakfast between 07:00 and 07:30 h, were admitted to the General Clinical Research Center of Di.M.I. at $\sim 08: 30 \mathrm{~h}$ and remained in the sitting position until the end of the studies. A hand vein of the non-dominant arm was cannulated retrogradely and maintained in a hot box $\left(\sim 60^{\circ} \mathrm{C}\right)$ for sampling of arterialized venous blood [15]. A superficial vein of the ipsilateral arm was also cannulated. The two veins were maintained patent by means of $0.9 \% \mathrm{NaCl}$ infusion $(0.5 \mathrm{ml} / \mathrm{min})$. At 09:30 h, an i.v. infusion of human regular insulin (diluted to $1 \mathrm{U} / \mathrm{ml}$ in $2 \mathrm{ml}$ of the subject's blood and $0.9 \% \mathrm{NaCl}$ to a final volume of $100 \mathrm{ml}$ ) was begun using a syringe pump (Harvard Apparatus, Ealing, South Natick, Mass., USA) to maintain plasma glucose at $\sim 7.2 \mathrm{mmol} / \mathrm{l}$ according to an algorithm described previously [16], and continued until 12:00 h (time $0 \mathrm{~min}$ ). At 12:00 $\mathrm{h}$ a standard meal was served and eaten in 15 to 20 min (Fig. 1). On two occasions, the meal consisted of $52 \mathrm{~g}$ of carbohydrates (450 Kcal, $46 \%$ carbohydrate, $32 \%$ lipids, $22 \%$ proteins) (standard $\mathrm{CHO}$ meal), whereas on the remaining two occasions $26 \mathrm{~g}$ of carbohydrates (450 Kcal, $23 \%$ carbohydrate, $55 \%$ lipids, $22 \%$ proteins) (low CHO meal) were administered. In all studies a s.c. injection of rapid-acting insulin was given prior to meal. On two occasions (standard and low $\mathrm{CHO}$, respectively), $0.15 \mathrm{U} / \mathrm{Kg}$ of human regular insulin was injected $30 \mathrm{~min}$ before the meal into the s.c. tissue $3 \mathrm{~cm}$ to the right or left of umbilicus. On the other two occasions (meal 52 or $26 \mathrm{~g}$ of carbohydrates), $0.15 \mathrm{U} / \mathrm{Kg}$ of the rapid-acting insulin analogue lispro were injected $1 \mathrm{~min}$ before the meal. Blood glucose samples for bedside measurements of plasma glucose concentrations were drawn every 5 to $7 \mathrm{~min}$ until $5 \mathrm{~h}$. In these studies glucose was infused when plasma glucose decreased below $3 \mathrm{mmol} / \mathrm{l}$ to prevent a further decrease below $2.8 \mathrm{mmol} / \mathrm{l}$.

Effect of rate of decreasing postprandial plasma glucose on responses to clamped hypoglycaemia. All 11 patients were studied on three different occasions at random order, at 3- to 4week intervals (slow and fast-fall study) at least 1 month after the studies described above. Over the week before the studies began, care was taken to avoid preprandial, postprandial and nocturnal blood glucose at less than $4.0 \mathrm{mmol} / \mathrm{l}$ [14]. On the 


\section{PLASMA GLUCOSE}

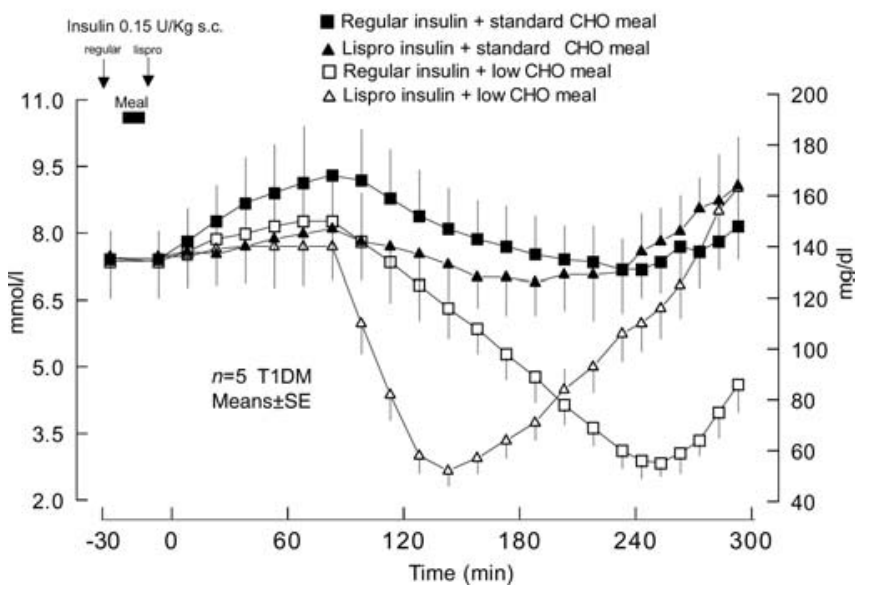

Fig. 1. Plasma glucose concentrations after ingestion of a standard mixed meal with "normal" carbohydrate (CHO) content $(52 \mathrm{~g})$ or low $\mathrm{CHO}$ content $(26 \mathrm{~g})$ and s.c. injection of $0.15 \mathrm{U} / \mathrm{Kg}$ human regular insulin or rapid-acting insulin analogue lispro. Glucose was infused i.v. whenever plasma glucose decreased to or below $3.1 \mathrm{mmol} / 1$ to prevent a further decrease below $2.8 \mathrm{mmol} / \mathrm{l}$

day prior to the studies, patients had their usual insulin treatment with the last s.c. NPH insulin injection at $\sim 23: 00 \mathrm{~h}$. On the morning of the studies, patients had their usual s.c. lispro insulin injection at breakfast between 07:00 and 07:30 h, and were admitted to the General Clinical Research Center of Di.M.I. at $\sim 08: 30 \mathrm{~h}$ and remained in the sitting position until the end of the studies. As described above, a hand vein of the non-dominant arm and a superficial vein of the ipsilateral arm were cannulated except that a hot pad was used instead of a box for logistical reasons for sampling arterialized-venous blood. In addition, a deep antecubital vein of the dominant arm was cannulated and maintained patent with $0.9 \% \mathrm{NaCl}$ $(0.1 \mathrm{ml} / \mathrm{min})$. At 09:30 h, an i.v. infusion of human regular insulin was begun to maintain plasma glucose at $5.5 \mathrm{mmol} / \mathrm{l}$ as described above and continued until 12:00 h (time 0 min). A lunch (mixed meal of $450 \mathrm{Kcal}, 46 \%$ carbohydrate, $32 \%$ lipids, $22 \%$ proteins) was served at $12: 00 \mathrm{~h}$ and eaten in 15 to $20 \mathrm{~min}$. At 12:00 h (time $0 \mathrm{~min}$ ), the rate of i.v. insulin infusion was increased to $2 \mathrm{mU} \cdot \mathrm{kg}^{-1} \cdot \mathrm{min}^{-1}$ until $15: 25 \mathrm{~h}$ (time $205 \mathrm{~min}$ ). Thereafter, the rate of insulin infusion was reduced to 0.15 $\mathrm{mU} \cdot \mathrm{kg}^{-1} \cdot \mathrm{min}^{-1}$ and continued until the end of the studies (16:35 h, $285 \mathrm{~min})$. After 12:00 h (0 min), glucose was infused i.v. at a variable rate to maintain plasma glucose on one occasion (euglycaemic study) at the target of $5.5 \mathrm{mmol} / \mathrm{l}$ throughout the study. On a second occasion, plasma glucose was maintained at $5.5 \mathrm{mmol} / \mathrm{l}$ until $75 \mathrm{~min}$ (slow-fall study) or $135 \mathrm{~min}$ (fast-fall study). After 75 min (slow-fall) or 135 min (fast-fall), respectively, the rate of glucose infusion was decreased to reach the target plasma glucose plateau of $2.4 \mathrm{mmol} / \mathrm{l}$ at $165 \mathrm{~min}$ in both studies. Such a hypoglycaemic plateau was maintained until $205 \mathrm{~min}$. After $205 \mathrm{~min}$, in both studies the rate of glucose infusion was increased to restore euglycaemia in $10 \mathrm{~min}$ and maintain euglycaemia for $70 \mathrm{~min}$ until the end of the studies (285 $\mathrm{min}$ ).

In the slow-fall study, a decrease in plasma glucose concentrations from euglycaemia to a hypoglycaemia plateau of $2.4 \mathrm{mmol} / \mathrm{l}$, was planned to occur three times more than as in the fast-fall study ( 90 vs $30 \mathrm{~min}$, respectively). This corresponded to a rate of plasma glucose decrease of $0.03 \mathrm{mmol}$.
$1^{-1} \cdot \min ^{-1}$ which was chosen for reproducing the result of the studies described above with postprandial hypoglycaemia with s.c. human regular insulin and low carbohydrate content of the meal. After a 40-min plateau of hypoglycaemia (at $205 \mathrm{~min}$ ), the plasma glucose concentration was planned to increase to euglycaemia as a result of a decrease in the insulin infusion rate to the -60 to $0 \mathrm{~min}$ insulin needs, as well as infusion of plasma glucose at a variable rate.

In the fast-fall study, the decrease in plasma glucose concentration from euglycaemia to a hypoglycaemia plateau of $2.4 \mathrm{mmol} / \mathrm{l}$ was planned to occur over $30 \mathrm{~min}$, i.e. at a rate three times faster than in the slow-fall study. This corresponded to a rate of plasma glucose decrease of $0.1 \mathrm{mmol} \cdot 1^{-1} \cdot \mathrm{min}^{-1}$. This rate was chosen to reproduce the result of the studies described above with postprandial hypoglycaemia with s.c. lispro insulin and low carbohydrate content of the meal. After a 40-min hypoglycaemia plateau, the plasma glucose concentration was planned to increase to euglycaemia as described above in the slow-fall study.

In all studies, blood was drawn at 5- to 10-min intervals for plasma glucose measurement, and at baseline (at $-30 \mathrm{~min}$ and $0 \mathrm{~min}$ ), during hypoglycaemia (at 185, 195 and $205 \mathrm{~min}$ ), and after recovery from hypoglycaemia (at 265, 275 and $285 \mathrm{~min}$ ) for measurement of plasma insulin, counterregulatory hormone, pancreatic polypeptide, non-glucose substrate, concentrations and plasma $\left[{ }^{3} \mathrm{H}\right]$-noradrenaline radioactivity. At the same time intervals, forearm blood flow was measured (plethysmography) and a symptom questionnaire was given. Cognitive function was assessed over 15-min time intervals three times, at baseline ( -15 to $0 \mathrm{~min})$, during the hypoglycaemic plateau (190 to $205 \mathrm{~min}$ ), and after recovery of hypoglycaemia ( 270 to $285 \mathrm{~min}$ ) by means of a battery of psychometric tests.

Forearm $\left[{ }^{3} \mathrm{H}\right]$-noradrenaline kinetics. At 11:30 h (-30 min) a costant infusion of $10 \mathrm{nCi} \cdot \mathrm{kg}^{-1} 6 \cdot \mathrm{min}^{-1}$ of tritiated noradrenaline [levo-ring-2,5,6-[3 $\mathrm{H}]$-noradrenaline (specific activity 40-60 Ci/mmol; New England Nuclear, Boston, Mass., USA)] was begun and continued for $30 \mathrm{~min}$. During the last $10 \mathrm{~min}$, at the steady state, three blood samples were drawn simultaneously from the arterialized hand vein and the deep forearm vein at 5-min intervals (11:50, 11:55 and 12:00 h). Forearm blood flow was measured by using mercury-in-Silastic straingauge venous occlusion plethysmography. One strain gauge was placed in the widest part of the forearm of the dominant arm and connected to a plethysmograph (model EC-4, D.E. Hokanson, Issaquah, Wash., USA). One minute before each blood sampling, a wrist pressure cuff was inflated to $200 \mathrm{mmHg}$ to occlude hand blood flow. In addition, an arm cuff was inflated to $50 \mathrm{mmHg}$ (Hokanson E20 rapid cuff inflator, Hokanson) to occlude venous outflow from the forearm during blood flow measurements. Five blood flow measurements were recorded and averaged to obtain the mean blood flow value. Tritiated noradrenaline was infused again during hypoglycaemia between 175 and $205 \mathrm{~min}$ and during the recovery phase between 255 and $285 \mathrm{~min}$. Consequently, blood samples for forearm $\left[{ }^{3} \mathrm{H}\right]$-noradrenaline kinetics and blood flow measurements were repeated during hypoglycaemia at 195, 200 and $205 \mathrm{~min}$, and in the recovery phase at 275, 280 and $285 \mathrm{~min}$. A study [17] has validated the intermittent infusion of tritiated noradrenaline compared to continuous infusion to generate steady-state plasma specific activity of noradrenaline. The intermittent infusion of tritiated noradrenaline is routinely used to determine the spillover of noradrenaline [18, 19].

Symptoms. Symptoms were quantified by asking subjects to score $(0$, none, to 5 , severe) each of the following symptoms: 
dizziness, tingling, blurred vision, difficulty in thinking, faintness, anxiety, palpitations, hunger, sweating, irritability, or tremor. In accordance with previous classifications [20], the first five symptoms were considered neuroglycopenic and the last six autonomic. The sum of each of these constituted the symptom score.

Cognitive function. Cognitive function was assessed by administering the following tests: trail-making part A, trail-making part B, backward digit span, verbal memory test [20, 21], and paced auditory serial addition task (PASAT) [22]. This battery includes measures of attention (including sustained attention), memory, retrieval from semantic memory, psychomotor speed, and information processing. Subjects extensively practiced each test before baseline to minimize the practice effects. For the actual study, three alternate forms were prepared which were assigned randomly across test session.

Analytical methods. Plasma glucose was measured by a Beckman glucose analyzer (Glucose Analyzer II, Beckman Instruments, Fullerton, Calif., USA). Plasma insulin, glucagon, growth hormone, cortisol, adrenaline, noradrenaline and tritium-labelled noradrenaline, alanine, glycerol, $\beta-\mathrm{OH}$-butyrate, lactate, and pancreatic polypeptide, were measured by assays described previously [23, 24]. To remove antibody-bound insulin, plasma was mixed with an equal volume of $30 \%$ polyethylene glycol immediately after blood collection [25]. $\mathrm{HbA}_{1 \mathrm{c}}$ was determined by HPLC using a HI-Auto $\mathrm{A}_{1 \mathrm{c}}$ TM HA 8121 apparatus (DIC, Kyoto Daiichi, Kogaku, Japan) (range in non-diabetic subjects $3.8-5.5 \%$ ). Plasma NEFA concentration was measured using a commercial kit (Wako NEFA C test kit, Wako Chemicals, Neuss, Germany).

Calculations. The data obtained in the baseline period $(-30$, -15 and $0 \mathrm{~min})$, during the hypoglycaemia plateau $(185,195$ and $205 \mathrm{~min}$ ) and after recovery phase $(265,275$ and $285 \mathrm{~min})$ were used to calculate a mean value for each of the three periods. Therefore, the results are presented as a mean value for each of the three periods of the study.

Forearm spillover of noradrenaline was calculated with the following formula [18]: FNASO $\left(\mathrm{pmol} \cdot 100 \mathrm{ml}^{-1} \cdot \mathrm{min}^{-1}\right)=$ $\left[\left(\mathrm{NA}_{\mathrm{v}}-\mathrm{Na}_{\mathrm{a}}\right)+\left(\mathrm{NA}_{\mathrm{a}} \times \mathrm{FNA}_{\mathrm{ex}}\right)\right] \times \mathrm{FPF}$, where $\mathrm{NA}_{\mathrm{v}}$ and $\mathrm{NA}_{\mathrm{a}}$ are noradrenaline concentrations in the deep vein and arterial plasma respectively; FNA $_{e x}=\left(\left[{ }^{3} \mathrm{H}\right] \mathrm{NA}_{\mathrm{a}}-\left(\left[{ }^{3} \mathrm{H}\right] \quad \mathrm{NA}_{\mathrm{v}} /\left[{ }^{3} \mathrm{H}\right] \mathrm{NA}_{\mathrm{a}}\right)\right.$ is the forearm fractional extraction of noradrenaline calculated from the respective concentrations of ${ }^{3} \mathrm{H}$-labelled noradrenaline in the deep venous and arterial plasma; and FPF is the forearm plasma flow calculated as [(1-hematocrit $) \times$ forearm blood flow].

Mean blood pressure (MBP) was calculated by adding one third of the pulse pressure value to the diastolic pressure.

Forearm vascular resistances (FVR, mmHg.ml-1 $100 \mathrm{ml}^{-1}$ min $^{-1}$ ) was calculated by dividing mean blood pressure by forearm blood flow (FBF).

Statistical analysis. Data in text are given as means \pm SE and were considered to be significantly different at $p$ of less than 0.05. All data were subjected to repeated measures analysis of variance (ANOVA) with Huynh-Feldt adjustment for nonsphericity [26]. Post-hoc comparisons (Tukey test) were carried out to pinpoint specific differences on significant means of interaction. A modified Bonferroni procedure [27] for multiple cognitive test adjustments was used in to maintain an overall type 1 error rate of $5 \%$ (alpha=0.05). In addition, for plasmatic catecholamines adrenaline and noradrenaline, the areas under the curve (AUCs) were also calculated according to the trapezoidal rule. Exploratory stepwise regression analyses were done to identify independent variables which contributed best to predict cognitive performance during the recovery phase of hypoglycaemia [28]. Data in Tables $1,2,3,4,5$ are presented as mean values $( \pm \mathrm{SE})$ of baseline euglycaemia (-30 and $0 \mathrm{~min})$, plateau plasma glucose during hypoglycaemia or euglycaemia (135 to $165 \mathrm{~min}$ ), and euglycaemia after either recovery from hypoglycaemia or maintenance of euglycaemia (255 to $285 \mathrm{~min})$. Statistical analysis was carried out using Statistica (Release 4.5, StatSoft, 1993).

\section{Results}

Rate of fall in postprandial plasma glucose in response to human regular insulin and the rapid-acting insulin analogue lispro. After ingestion of standard $\mathrm{CHO}$ meal with s.c. lispro insulin, the peak of postprandial hyperglycaemia was lower than with human regular insulin [7.8 \pm 0.6 vs $9.3 \pm 0.8$, respectively, $p<0.05]$. When the carbohydrate content of the meal was low, postprandial hypoglycaemia (decrease of plasma glucose below $4 \mathrm{mmol} / \mathrm{l}$ ) occurred with both treatments. However, hypoglycaemia occurred earlier after lispro $(120 \pm 10 \mathrm{~min})$ as compared to human regular insulin $(220 \pm 16 \mathrm{~min})$ $(p<0.001)$. In these studies, glucose was infused in all subjects when plasma glucose decreased below $5 \mathrm{mmol} / \mathrm{l}$ to prevent a further decrease below $2.8 \mathrm{mmol} / \mathrm{l}$. The calculation of the rate of decreasing plasma glucose concentrations from the postprandial peak to $5 \mathrm{mmol} / \mathrm{l}$ observed before glucose infusion, yielded a value three times greater for lispro than for human regular insulin $[0.102+0.003$ vs $0.033+$ $0.001 \mathrm{mmol} \cdot \mathrm{min}^{-1} \cdot \mathrm{l}^{-1}$, respectively, $p<0.05$ ] (Fig. 1).

Effects of euglycaemia and induction of fast-fall or slow-fall hypoglycaemia: plasma glucose and insulin concentrations, and rates of glucose infusion. After a meal, during both insulin and glucose infusions, plasma glucose was maintained at euglycaemia $(5.7 \pm 0.05 \mathrm{mmol} / \mathrm{l})$ throughout the studies (euglycaemic study) or until $75 \mathrm{~min}$ in the slow-fall, and until $135 \mathrm{~min}$ in the fast-fall study. In the slow-fall study, the rate of glucose infusion was decreased after 75 min to reduce the plasma glucose concentration and reach the target hypoglycaemic plateau of $45 \pm 1.5 \mathrm{mg} / \mathrm{dl}$ at $165 \mathrm{~min}$ (rate of plasma glucose decrease of $0.03 \mathrm{mmol} \cdot \mathrm{l}^{-1} \cdot \mathrm{min}^{-1}$ ). Thereafter, plasma glucose concentration was maintained at the plateau of $2.4 \pm 0.04 \mathrm{mmol} / 1$ until $205 \mathrm{~min}$, and subsequently increased to $5.5 \pm 0.05 \mathrm{mmol} / \mathrm{l}$ at $215 \mathrm{~min}$ and maintained at $5.6 \pm 0.03 \mathrm{mmol} / \mathrm{l}$ until the end of the studies. In the fast-fall study, the rate of glucose infusion was decreased after $135 \mathrm{~min}$ to reach the hypoglycaemic value of $2.5 \pm 0.07 \mathrm{mmol} / \mathrm{l}$ by $165 \mathrm{~min}$ with a rate of decrease of $0.1 \mathrm{mmol} \cdot 1^{-1} \cdot \mathrm{min}^{-1}$. The subsequent hypoglycaemic plateau and recovery was superimposable to that of the slow-fall study (Fig. 2).

Plasma insulin concentrations were similar in all three studies at baseline $(66 \pm 6,72 \pm 7$ and $68 \pm 8 \mathrm{pmol} / \mathrm{l})$, during the euglycaemia or hypoglycae- 
Table 1. Plasma concentrations of glucagon, cortisol, growth hormone and pancreatic polypeptide in diabetic patients $(n=11)$

Baseline euglycaemia

$141 \pm 19$

$150 \pm 17$

$154 \pm 29$

$343 \pm 98$

$236 \pm 68$

$252 \pm 93$

Slow-fall

Fast-fall

Growth hormone $(\mu \mathrm{g} / \mathrm{l})$

Euglycaemia study

Hypoglycaemia study

Slow-fall

Fast-fall

Pancreatic polypeptide (pmol/l)

Euglycaemia study

Hypoglycaemia study

Slow-fall

Fast-fall

$$
\begin{aligned}
& 7.9 \pm 1.3 \\
& 4.9 \pm 2.2
\end{aligned}
$$

$8.0 \pm 2.8$

$74 \pm 8.0$

$86 \pm 11$

$68 \pm 7.6$
Plateau euglycaemia or hypoglycaemia

$153 \pm 20$

$209 \pm 32^{a}$

$189 \pm 35^{\mathrm{a}}$

$307 \pm 78$

$462 \pm 123^{a}$

$401 \pm 138^{a}$

$11.9 \pm 1.3$

$46.5 \pm 7.4^{\mathrm{a}}$

$37.2 \pm 9.9^{a}$
Final euglycaemia
$180 \pm 9.0$

$214 \pm 6.5^{\mathrm{a}, \mathrm{c}}$

$215 \pm 6.3^{\mathrm{a}, \mathrm{c}}$
$148 \pm 17$

$162 \pm 20$

$163 \pm 32$

$255 \pm 84$

$422 \pm 208^{a}$

$407 \pm 127$ a

$9.5 \pm 1.0$

$21.5 \pm 3.6^{\mathrm{b}}$

$27.9 \pm 5.8^{\mathrm{a}}$

${ }^{\mathrm{a}} \mathrm{p}<0.05$ vs baseline, ${ }^{\mathrm{b}} \mathrm{p}<0.05$ vs hypoglycaemia, ${ }^{\mathrm{c}} \mathrm{p}<0.05$ vs euglycaemia

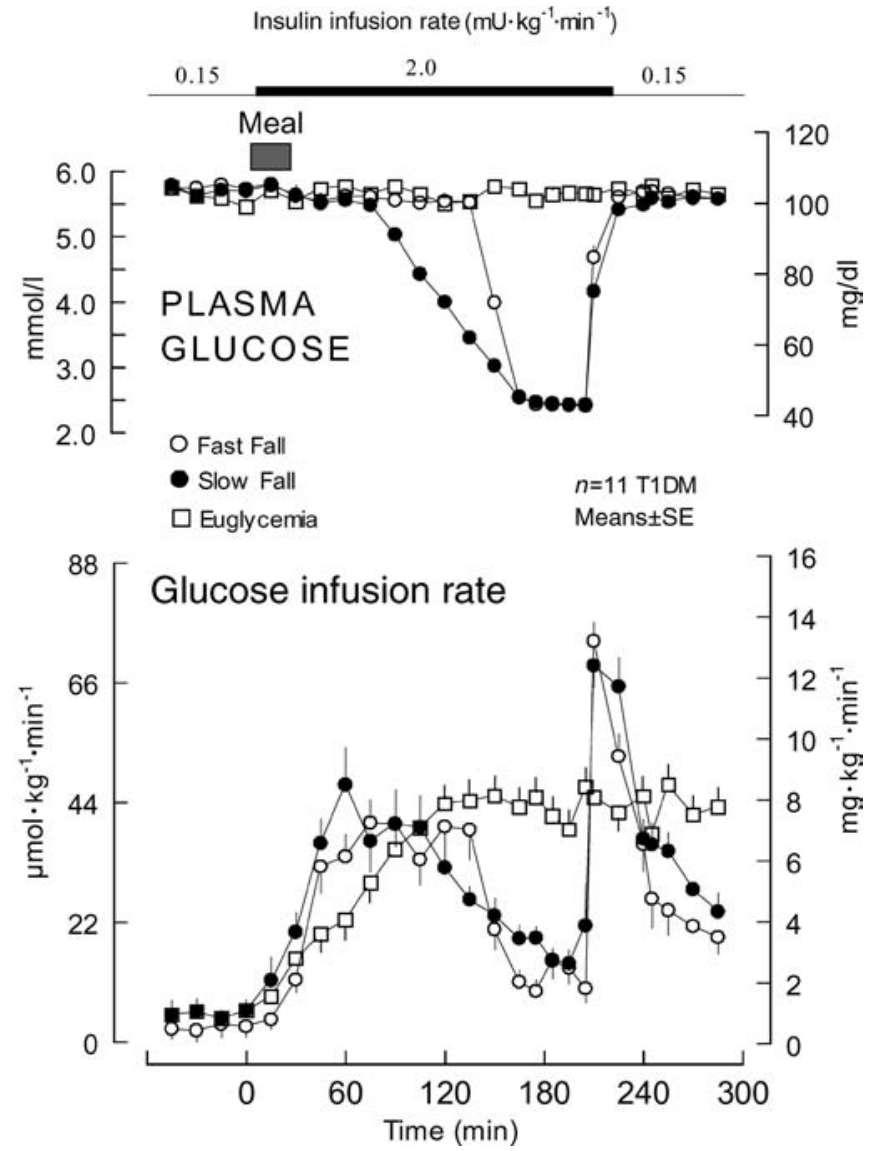

Fig. 2. Plasma glucose concentrations and rates of glucose infusion in the fast-fall and slow-fall hypoglycaemia studies and in the euglycaemia study mia plateau $(723 \pm 78,780 \pm 82$ and $756 \pm 77 \mathrm{pmol} / \mathrm{l})$ and during euglycaemia after either recovery from hypoglycaemia or maintenance of euglycaemia (82 \pm 9 , $78 \pm 10,71 \pm 9 \mathrm{pmol} / \mathrm{l}$ ) (euglycaemia study, slow-fall and fast-fall hypoglycaemia study, respectively, $p>0.05$ ).

The rates of glucose infusion were greater in euglycaemic than in hypoglycaemic clamp studies, as expected. In the hypoglycaemic clamp studies, the rates of glucose infusion were greater in the fast-fall than in the slow-fall study between 75 to $135 \mathrm{~min}$, $39.6 \pm 6.0$ versus $27.5 \pm 2.7 \mu \mathrm{mol} \cdot \mathrm{kg}^{-1} \cdot \mathrm{min}^{-1}(7.2 \pm 1.1 \mathrm{vs}$ $\left.5.0 \pm 0.5 \mathrm{mg} \cdot \mathrm{kg}^{-1} \mathrm{~min}^{-1}, p=0.04\right)$. However, in this part of the studies plasma glucose was maintained at euglycaemia in the fast-fall study whereas it was decreased in the slow-fall study. In the latter part of studies matched for plasma glucose concentration, the rates of glucose infusion during the hypoglycaemia plateau, of $11.9 \pm 2.2$ versus $17.5 \pm 2.2 \mu \mathrm{mol} \cdot \mathrm{kg}^{-1} \cdot \mathrm{min}^{-1}$ $\left(2.16 \pm 0.4\right.$ vs $\left.3.24 \pm 0.4 \mathrm{mg} \cdot \mathrm{kg}^{-1} \mathrm{~min}^{-1}\right)$ and the recovery, of $22.5 \pm 6.6$ vs $30.8 \pm 3.3 \mu \mathrm{mol} \cdot \mathrm{kg}^{-1} \mathrm{~min}^{-1}(4.1 \pm 0.7$ vs $5.6 \pm 0.6 \mathrm{mg} \cdot \mathrm{kg}^{-1} \mathrm{~min}^{-1}$ ) were not different in the two studies (fast vs slow, respectively, $p>0.05$ ).

Plasma counterregulatory hormones concentrations, forearm blood flow, vascular resistances and noradrenaline spillover. All counterregulatory hormone and pancreatic polypeptide (PP) concentrations were higher in the hypoglycaemia studies than in the euglycaemia studies. There was a trend for greater responses of the counterregulatory hormones, glucagon, cortisol and growth hormone (Table 1), and plasma adrenaline 

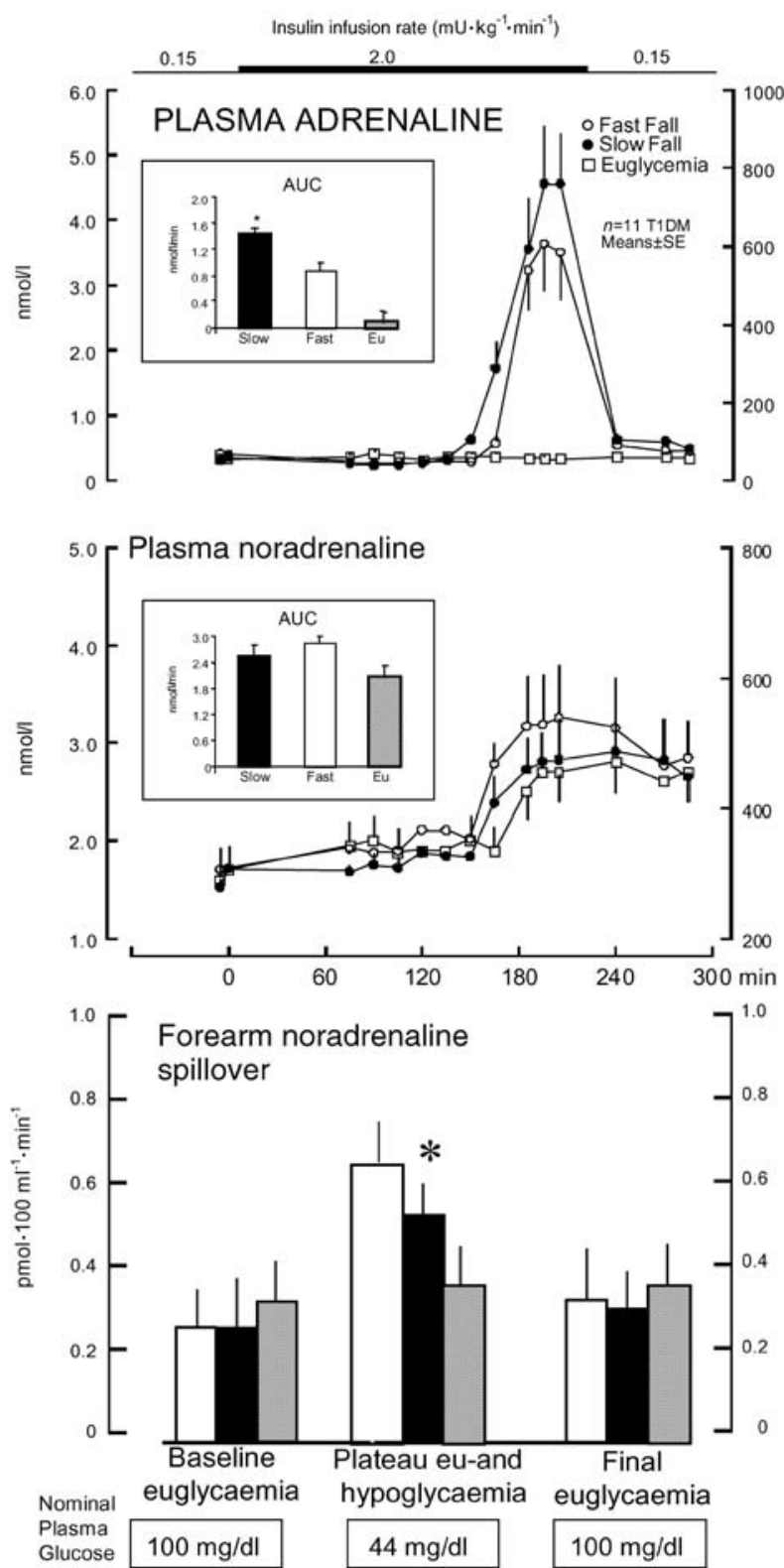

Fig. 3. Plasma adrenaline and noradrenaline concentrations, and forearm noradrenaline spillover in the fast-fall and slowfall hypoglycaemia studies and in the euglycaemia study. Inserts depict adrenaline and noradrenaline areas $\left(\mathrm{AUC}_{0-285 \mathrm{~min}}\right)$

(Fig. 3) to increase more in the slow-fall study, but the difference was statistically significant only for adrenaline. Plasma adrenaline increased earlier (at $160 \mathrm{~min}$, $1.6 \pm 0.4$ vs $0.5 \pm 0.1 \mathrm{nmol} / 1, p=0.01$ ) and peaked to a greater value $(4.6 \pm 0.8 \mathrm{nmol} / \mathrm{l})$ in the slow as compared to the fast-fall study $(3.6 \pm 0.6 \mathrm{nmol} / \mathrm{l})$, respectively ( $p=0.04)$. As a result, the overall plasma adrenaline response to hypoglycaemia was greater in the slow-fall than in the fast-fall study (the area under the adrenaline curve was $1.4 \pm 0.25$ and $0.9 \pm 0.14 \mathrm{nmol} \cdot \mathrm{l}^{-1}$ $\mathrm{min}^{-1}$, respectively, $p=0.01$ ). After recovery from hypoglycaemia, plasma glucagon and adrenaline decreased to values no different from baseline. In contrast, plasma cortisol, growth hormone, pancreatic polypeptide (Table 1) and plasma noradrenaline, remained increase as compared to the baseline with no differences between studies (Tables 1, 2, Fig. 3).

Forearm blood flow, systolic, diastolic and mean blood pressure and forearm vascular resistances did not change in the euglycaemia study. In contrast, forearm blood flow and systolic blood pressure increased, and diastolic, mean blood pressure and forearm vascular resistances decreased during hypoglycaemia and returned to baseline after recovery with no differences between studies (Table 2). Plasma noradrenaline response and noradrenaline spillover rates were greater in the fast-fall study, but only the latter reached statistical significance $(0.7 \pm 0.09$ vs $0.5 \pm 0.06 \mathrm{pmol}$. $\mathrm{min}^{-1} \cdot 100 \mathrm{ml}^{-1}$, fast vs slow-fall study, $p=0.040$ ) (Fig. 3).

Plasma non-glucose substrate concentrations. Baseline plasma NEFA, $\beta$-OH-butyrate and glycerol concentrations were similar in all studies. Plasma NEFA and $\beta$-OH-butyrate concentrations were suppressed throughout the euglycaemia study. Plasma NEFA and $\beta$-OH-butyrate were also suppressed in the hypoglycaemia studies and returned to baseline values after recovery with no differences between studies. Also plasma glycerol concentration tended to decrease during hypoglycaemia, but the decrease was not statistically significant in either of the two studies. After recovery of hypoglycaemia, however, plasma glycerol increased above baseline values similarly in both studies. Plasma lactate concentration increased in the hypoglycaemia studies more than in the euglycaemia studies and returned to baseline after recovery with no differences between studies. In these studies where hypoglycaemia was induced in the postprandial state, plasma alanine concentration did not decrease as it usually does in insulin-induced hypoglycaemia in the fasting state [29], but instead it increased during hypoglycaemia and remained increased above baseline in the recovery phase from hypoglycaemia with no differences between studies. This was likely due to meal ingestion as shown by the euglycaemia study (Table 3).

Symptom responses. Symptoms did not change in the euglycaemia study. Both autonomic and neuroglycopenic symptoms increased in response to hypoglycaemia to a similar extent in the slow-fall and in the fast-fall study. Both symptoms decreased in the recovery phase to values no different from baseline, with no differences between the slow and fast-fall study (Table 4).

Cognitive tests. Cognitive tests did not change in the euglycaemia studies. All seven cognitive test deteriorated during hypoglycaemia both after fast-fall and slow-fall, with the exception of the digit vigilance test which deteriorated only after the fast-fall and margin- 
Table 2. Forearm noradrenaline spillover, forearm blood flow, mean blood pressure and forearm vascular resistances in diabetic patients $(n=11)$

Baseline euglycaemia Plateau euglycaemia

Final Euglycaemia or hypoglycaemia

Forearm blood flow $\left(\mathrm{ml} \cdot 100 \mathrm{ml}^{-1} \cdot \mathrm{min}^{-1}\right)$

Euglycaemia study

Hypoglycaemia study $\quad 2.6 \pm 0.2$

Slow-fall $\quad 2.5 \pm 0.2$

$2.6 \pm 0.1$

$2.9 \pm 0.2$

$4.4 \pm 0.4 \mathrm{a}, \mathrm{b}$

$4.3 \pm 0.4 \mathrm{a}, \mathrm{b}$

$2.8 \pm 0.1$

Fast-fall

Systolic blood pressure ( $\mathrm{mmHg}$ )

Euglycaemia study

Hypoglycaemia study $\quad 124 \pm 2.0$

Slow-fall $\quad 125 \pm 1.9$

Fast-fall

$122 \pm 1.8$

Diastolic blood pressure ( $\mathrm{mmHg}$ )

Euglycaemia study

Hypoglycaemia study $\quad 72 \pm 0.8$

Slow-fall $\quad 73 \pm 1.2$

Fast-fall

$76 \pm 1.1$

Mean blood pressure $(\mathrm{mmHg})$

Euglycaemia study

$\begin{array}{ll}\text { Hypoglycaemia study } & 89 \pm 1.4 \\ \text { Slow-fall } & 90 \pm 1.4\end{array}$

Fast-fall $\quad 91 \pm 1.6$

Forearm vascular resistances $\left(\mathrm{mmHgimli} 100 \mathrm{ml}^{-1} \cdot \mathrm{min}^{-1}\right)$

Euglycaemia study

Hypoglycaemia study $\quad 34 \pm 2.0$

Slow-fall $\quad 36 \pm 2.9$

Fast-fall $\quad 35 \pm 1.9$
$123 \pm 1.7$

$128 \pm 1.5^{\mathrm{a}, \mathrm{b}}$

$70 \pm 1.2$

$59 \pm 0.9 \mathrm{a}, \mathrm{b}$

$57 \pm 0.9^{a}$, b

$87 \pm 1.3$

$82 \pm 0.8^{a}$

$83 \pm 1.1^{\mathrm{a}}$

$30 \pm 2.2$

$19 \pm 2.1^{\mathrm{a}}$

$20 \pm 1.8^{\mathrm{a}}$
$130 \pm 2.0^{\mathrm{a}, \mathrm{b}}$
$124 \pm 1.8$

$127 \pm 2.0$

$125 \pm 1.7$

$74 \pm 1.1$

$73 \pm 0.9$

$76 \pm 1.2$

$90 \pm 1.1$

$91 \pm 1.1$

$92 \pm 1.5$

${ }^{\mathrm{a}} p<0.05$ vs baseline, ${ }^{\mathrm{b}} p<0.05$ vs euglycaemia, ${ }^{\mathrm{c}} p<0.05$ vs slow-fall study

ally after the slow-fall study $(p=0.06)$ (Table 5). In all hypoglycaemia mediated cognitive tests deterioration was greater in the fast-fall than after the slow-fall study. Significant differences were, however, only seen for Trail-Making B, PASAT (2 s), digit vigilance and verbal memory tests. After recovery from hypoglycaemia, all cognitive tests remained deteriorated compared with the baseline, with the exception of digit span backward and digit vigilance, without differences between the fast and slow-fall studies. In a stepwise regression analysis, correlations between age, diabetes duration, percentage of $\mathrm{HbA}_{1 \mathrm{c}}$, plasma concentration of hormones and metabolites during the recovery phase of hypoglycaemia, and the degree of deterioration of cognitive tests also in the recovery phase of hypoglycaemia were calculated (Table 6). The protracted deterioration of the Trail making A and B tests after recovery from hypoglycaemia was best predicted by the duration of diabetes ; the responses of PASAT tests (both $4 \mathrm{~s}$ and $2 \mathrm{~s}$ ) were best predicted by pancreatic polypeptide concentrations; and the verbal memory test was best predicted by the percentage of $\mathrm{HbA}_{1 \mathrm{c}}$ (Tables 5, 6).

\section{Discussion}

Our studies indicate that in patients with Type I diabetes the responses to hypoglycaemia differ in the postprandial state and sitting position, depending on the rate of fall of blood glucose concentrations. When it falls rapidly, the activation of the peripheral sympathetic nervous system is apparently greater than a subsequent slow fall of blood glucose. In parallel, the responses of adrenaline are also more markedly reduced and the impairment in cognitive function is greater. These findings contrast with the general assumption that the rate of decreasing blood glucose concentrations does not affect responses to hypoglycaemia [4, $5,6,7]$. Because the fast fall of hypoglycaemia does not potentiate the emergence of symptoms, our studies indicate that a fast fall in blood glucose potentially carries it over a greater risk for severe hypoglycaemia than a slow fall of blood glucose. The results also indicate that after recovery of hypoglycaemia, neither the plasma counterregulatory hormone concentration, nor the symptom score are affected by the rate of decreasing blood glucose to hypoglycaemia. This result extends also to cognitive function which remains im- 
Table 3. Plasma concentrations of free fatty acids, $\beta$-OH-hydroxybutyrate, glycerol, lactate and alanine in diabetic patients $(n=11)$

\begin{tabular}{|c|c|c|c|}
\hline & Baseline euglycaemia & $\begin{array}{l}\text { Plateau euglycaemia } \\
\text { or hypoglycaemia }\end{array}$ & Final euglycaemia \\
\hline \multicolumn{4}{|l|}{$\operatorname{NEFA}(\mu \mathrm{mol} / \mathrm{l})$} \\
\hline $\begin{array}{l}\text { Hypoglycaemia study } \\
\text { Slow-fall } \\
\text { Fast-fall }\end{array}$ & $\begin{array}{l}270 \pm 45 \\
259 \pm 50 \\
305 \pm 43\end{array}$ & $\begin{array}{r}99 \pm 20^{\mathrm{a}} \\
120 \pm 15^{\mathrm{a}} \\
134 \pm 26^{\mathrm{a}}\end{array}$ & $\begin{array}{c}73 \pm 18^{a} \\
213 \pm 37 \\
233 \pm 32\end{array}$ \\
\hline \multicolumn{4}{|c|}{$\begin{array}{l}\beta \text {-OH-hydroxybutyrate }(\mu \mathrm{mol} / \mathrm{l}) \\
\text { Euglycaemia study }\end{array}$} \\
\hline $\begin{array}{l}\text { Hypoglycaemia study } \\
\text { Slow-fall } \\
\text { Fast-fall }\end{array}$ & $\begin{array}{l}265 \pm 21 \\
294 \pm 35 \\
319 \pm 29\end{array}$ & $\begin{array}{l}112 \pm 24^{\mathrm{a}} \\
201 \pm 22^{\mathrm{a}} \\
208 \pm 22^{\mathrm{a}}\end{array}$ & $\begin{array}{c}95 \pm 17 \mathrm{a} \\
332 \pm 35 \\
341 \pm 50\end{array}$ \\
\hline \multicolumn{4}{|l|}{$\begin{array}{l}\text { Glycerol }(\mu \mathrm{mol} / \mathrm{l}) \\
\text { Euglycaemia study }\end{array}$} \\
\hline $\begin{array}{l}\text { Hypoglycaemia study } \\
\text { Slow-fall } \\
\text { Fast-fall }\end{array}$ & $\begin{array}{l}80 \pm 12 \\
88 \pm 18 \\
77 \pm 14\end{array}$ & $\begin{array}{l}73 \pm 14 \\
76 \pm 15 \\
79 \pm 16\end{array}$ & $\begin{array}{c}71 \pm 13 \\
102 \pm 16^{\mathrm{b}} \\
105 \pm 16^{\mathrm{a}}, \mathrm{b}\end{array}$ \\
\hline \multicolumn{4}{|l|}{$\begin{array}{l}\text { Lactate }(\mathrm{mmol} / \mathrm{l}) \\
\text { Euglycaemia study }\end{array}$} \\
\hline $\begin{array}{l}\text { Hypoglycaemia study } \\
\text { Slow-fall } \\
\text { Fast-fall }\end{array}$ & $\begin{array}{l}0.8 \pm \\
0.9 \pm 0.1 \\
1.1 \pm 0.1\end{array}$ & $\begin{array}{l}1.2 \pm 0.1 \\
1.6 \pm 0.2^{\mathrm{a}} \\
1.8 \pm 0.2^{\mathrm{a}}\end{array}$ & $\begin{array}{l}1.2 \pm 0.1 \\
1.2 \pm 0.1 \\
1.4 \pm 0.2\end{array}$ \\
\hline \multicolumn{4}{|l|}{$\begin{array}{l}\text { Alanine ( } \mu \mathrm{mol} / \mathrm{l}) \\
\text { Euglycaemia study }\end{array}$} \\
\hline $\begin{array}{l}\text { Hypoglycaemia study } \\
\text { Slow-fall } \\
\text { Fast-fall }\end{array}$ & $\begin{array}{l}360 \pm 30 \\
305 \pm 29 \\
324 \pm 25\end{array}$ & $\begin{array}{l}400 \pm 33 \\
380 \pm 37^{a} \\
387 \pm 23^{a}\end{array}$ & $\begin{array}{l}390 \pm 28 \\
362 \pm 30^{\mathrm{a}} \\
402 \pm 29^{\mathrm{a}}\end{array}$ \\
\hline
\end{tabular}

${ }^{\mathrm{a}} p<0.05$ vs baseline, ${ }^{\mathrm{b}} p<0.05$ vs hypoglycaemia

Table 4. Autonomic and neuroglycopenic symptoms in diabetic patients $(n=11)$

Baseline euglycaemia Plateau euglycaemia

Final euglycaemia or hypoglycaemia

Autonomic symptoms (score)

Euglycaemia study

Hypoglycaemia study $\quad 0.5 \pm 0.3$

Slow-fall $\quad 0.6 \pm 0.3$

$\begin{array}{ll}1.1 \pm 1.0 & 1.0 \pm 0.8\end{array}$

$5.1 \pm 1.4^{\mathrm{a}} \quad 2.2 \pm 0.5$

Fast-fall

$0.6 \pm 0.4$

$\begin{array}{ll}6.1 \pm 1.4^{\mathrm{a}} & 2.1 \pm 0.5\end{array}$

Neuroglycopenic symptoms (score)

Euglycaemia study

$\begin{array}{ll}\text { Hypoglycaemia study } & 0.6 \pm 0.3 \\ \text { Slow-fall } & 0.4 \pm 0.4\end{array}$

\begin{tabular}{ll} 
Fast-fall & $0.4 \pm 0.2$ \\
\hline
\end{tabular}

$0.9 \pm 0.7 \quad 0.9 \pm 0.6$

$2.8 \pm 0.8^{\mathrm{a}} \quad 1.0 \pm 0.5$

$3.5 \pm 0.9^{\mathrm{a}} \quad 0.6 \pm 0.2$

${ }^{\text {a }} p<0.05$ vs baseline

paired after hypoglycaemia is corrected. An unexpected finding of these studies is the response of glucagon to the postprandial condition of hypoglycaemia which contrasts with the well known lack of glucagon response to hypoglycaemia in the fasting state [30, 31]. Thus, the postprandial state is involved in the responses of glucagon to hypoglycaemia in addition to previ- ously identified factors such as peripheral plasma insulin concentration [32].

A number of studies have examined the the role of rate of decreasing blood glucose concentrations on responses to hypoglycaemia, and concordantly found no effects either in non-diabetic subjects [7] or in Type I diabetic patients $[4,5,6]$. In those studies, however, 
Table 5. Cognitive test scores in diabetic patients

\begin{tabular}{|c|c|c|c|}
\hline & Baseline euglycaemia & $\begin{array}{l}\text { Plateau euglycaemia } \\
\text { or hypoglycaemia }\end{array}$ & Final euglycaemia \\
\hline $\begin{array}{l}\text { Trail-Making A }{ }^{a} \\
\text { Euglycaemia study }\end{array}$ & \multicolumn{3}{|c|}{ Trail-Making A ${ }^{\mathrm{a}}$} \\
\hline $\begin{array}{l}\text { Hypoglycaemia study } \\
\text { Slow-fall } \\
\text { Fast-fall }\end{array}$ & $\begin{array}{l}45 \pm 12 \\
43.3 \pm 11.4 \\
40.5 \pm 10.3\end{array}$ & $\begin{array}{l}49 \pm 11 \\
101.9 \pm 22.2^{\mathrm{f}} \\
111.7 \pm 22.2^{\mathrm{f}}\end{array}$ & $\begin{array}{l}55 \pm 10 \\
101.7 \pm 18.6^{\mathrm{f}} \\
106.3 \pm 20.6^{\mathrm{f}}\end{array}$ \\
\hline \multicolumn{4}{|l|}{$\begin{array}{l}\text { Trail-Making } \mathrm{B}^{\mathrm{a}} \\
\text { Euglycaemia study }\end{array}$} \\
\hline $\begin{array}{l}\text { Hypoglycaemia study } \\
\text { Slow-fall } \\
\text { Fast-fall }\end{array}$ & $\begin{array}{l}71 \pm 10 \\
70.6 \pm 11.2 \\
70.2 \pm 11\end{array}$ & $\begin{array}{l}68 \pm 11 \\
114.2 \pm 23.1^{\mathrm{f}} \\
130.8 \pm 22.4^{\mathrm{f}, \mathrm{g}}\end{array}$ & $\begin{array}{l}75 \pm 14 \\
95.8 \pm 23.2^{\mathrm{f}} \\
99.3 \pm 23.5^{\mathrm{f}}\end{array}$ \\
\hline \multicolumn{4}{|l|}{$\begin{array}{l}\text { PASAT }(4 \mathrm{~s})^{\mathrm{b}} \\
\text { Euglycaemia study }\end{array}$} \\
\hline $\begin{array}{l}\text { Hypoglycaemia study } \\
\text { Slow-fall } \\
\text { Fast-fall }\end{array}$ & $\begin{array}{l}2.5 \pm 0.7 \\
2.6 \pm 0.9 \\
2.8 \pm 0.8\end{array}$ & $\begin{array}{l}2.5 \pm 0.8 \\
3.9 \pm 0.7^{f} \\
4.5 \pm 0.7^{f}\end{array}$ & $\begin{array}{l}2.8 \pm 0.7 \\
3.7 \pm 1.0^{f} \\
3.8 \pm 1.0^{f}\end{array}$ \\
\hline \multicolumn{4}{|l|}{$\begin{array}{l}\operatorname{PASAT}(2 \mathrm{~s})^{\mathrm{b}} \\
\text { Euglycaemia study }\end{array}$} \\
\hline $\begin{array}{l}\text { Hypoglycaemia study } \\
\text { Slow-fall } \\
\text { Fast-fall }\end{array}$ & $\begin{array}{l}6.0 \pm 0.6 \\
5.6 \pm 0.4 \\
5.9 \pm 0.5\end{array}$ & $\begin{array}{l}6.2 \pm 0.8 \\
6.8 \pm 0.7^{f} \\
9.3 \pm 0.6^{f, g}\end{array}$ & $\begin{array}{l}6.3 \pm 0.8 \\
4.5 \pm 1.1^{\mathrm{f}} \\
5.5 \pm 1.1^{\mathrm{f}}\end{array}$ \\
\hline \multicolumn{4}{|l|}{$\begin{array}{l}\text { Digit span backwardc } \\
\text { Euglycaemia study }\end{array}$} \\
\hline $\begin{array}{l}\text { Hypoglycaemia study } \\
\text { Slow-fall } \\
\text { Fast-fall }\end{array}$ & $\begin{array}{l}5.0 \pm 0.4 \\
4.9 \pm 0.3 \\
4.6 \pm 0.3\end{array}$ & $\begin{array}{l}5.3 \pm 0.3 \\
3.8 \pm 0.3^{\mathrm{f}} \\
3.5 \pm 0.2^{\mathrm{f}}\end{array}$ & $\begin{array}{l}5.3 \pm 0.4 \\
4.4 \pm 0.3 \\
4.5 \pm 0.2\end{array}$ \\
\hline \multicolumn{4}{|l|}{$\begin{array}{l}\text { Digit vigilance test } \\
\text { Euglycaemia study }\end{array}$} \\
\hline $\begin{array}{l}\text { Hypoglycaemia study } \\
\text { Slow-fall } \\
\text { Fast-fall }\end{array}$ & $\begin{array}{l}47 \pm 3.4 \\
46 \pm 3.9 \\
44 \pm 3.5\end{array}$ & $\begin{array}{l}46 \pm 3.5 \\
39.3 \pm 4.5 \\
31.7 \pm 4.6^{\mathrm{f}, \mathrm{g}}\end{array}$ & $\begin{array}{l}48 \pm 3.8 \\
41.5 \pm 3.4 \\
40.6 \pm 3.9\end{array}$ \\
\hline \multicolumn{4}{|l|}{$\begin{array}{l}\text { Verbal memory teste } \\
\text { Euglycaemia study }\end{array}$} \\
\hline $\begin{array}{l}\text { Hypoglycaemia study } \\
\text { Slow-fall } \\
\text { Fast-fall }\end{array}$ & $\begin{array}{l}5.0 \pm 0.3 \\
4.8 \pm 0.1 \\
4.6 \pm 0.2\end{array}$ & $\begin{array}{l}5.2 \pm 0.4 \\
3.3 \pm 0.3^{\mathrm{f}} \\
2.1 \pm 0.1^{\mathrm{f}, \mathrm{g}}\end{array}$ & $\begin{array}{l}5.4 \pm 0.1 \\
4.1 \pm 0.1^{\mathrm{f}} \\
4.0 \pm 0.2^{\mathrm{f}}\end{array}$ \\
\hline
\end{tabular}

a Time (s) required to complete the task, ${ }^{b}$ number of incorrect responses, ${ }^{c}$ number of digit sequences correctly repeated, ${ }^{d}$ number of correct targets crossed out in $90 \mathrm{~s},{ }^{\mathrm{f}} p<0.05$ vs baseline, ${ }^{\mathrm{g}} p<0.05$ vs slow-fall study

hypoglycaemia was induced in the fasting state and in the lying position $[4,5,6,7]$. In our studies, subjects with Type I diabetes were examined in the postprandial condition and sitting position to mimic real life. A model of slow- and fast-fall hypoglycaemia was designed to reproduce observations of rate of decreasing postprandial blood glucose after s.c. injection of rapid-acting insulin and reduced carbohydrate content of the meal . In this model, human regular insulin produced slow-fall hypoglycaemia (plasma glucose $<4 \mathrm{mmol} / \mathrm{l}$ within about $220 \mathrm{~min}$, and lispro insulin produced fast-fall hypoglycaemia in about $120 \mathrm{~min}$ after s.c. injection, as observed previously [33, 34]. In addition, in the present studies, subjects were studied in the sitting position, a posture which stimulates the baroceptor reflexes [42] and results in enhanced symptom and plasma adrenaline responses to hypoglycaemia [12].

The responses of counterregulatory hormones tended to be greater after the slow-fall as compared to fastfall study, although only the difference in adrenaline reached statistical significance. This result is at variance with previous studies $[6,7]$ where no differences in adrenaline responses were found. We interpret our finding of greater responses of adrenaline to slow-fall hypoglycaemia, primarily as the consequence of the 
Table 6. Independent variables which predicted best the cognitive test scores during the terminal euglycaemia

Independent variable

$R^{2} \quad R \quad p$

Trail-Making A

Slow-fall study

Fast-fall study

Diabetes duration

$\begin{array}{lll}0.68 & -0.82 & 0.002\end{array}$

$\begin{array}{llll}\text { Diabetes duration } & 0.53 & -0.73 & 0.01\end{array}$

Trail-Making B

Slow-fall study

Fast-fall study

Diabetes duration

Diabetes duration

0.69

$-0.83 \quad 0.001$

PASAT (4 s)

Slow-fall study

Fast-fall study

\begin{abstract}
$\mathrm{HbA}_{1 \mathrm{c}}$
P P
\end{abstract}

$0.34-0.58$

$0.37-0.61$

0.06

$\operatorname{PASAT}(2 \mathrm{~s})$

Slow-fall study

Fast-fall study

$$
\mathrm{HbA}_{1 \mathrm{c}}
$$

0.42

0.36

$-0.65$

$-0.60$

0.03

Verbal memory test

\begin{tabular}{lllll} 
Slow-fall study & $\mathrm{HbA}_{1 \mathrm{c}}$ & 0.28 & -0.53 & 0.09 \\
Fast-fall study & $\mathrm{HbA}_{1 \mathrm{c}}$ & 0.62 & -0.78 & 0.004 \\
\hline
\end{tabular}

blood-glucose decrease below the threshold of response at an earlier time compared to the fast-fall study. In fact, the duration of hypoglycaemia was greater in the slow-fall compared to fast-fall hypoglycaemia by about $30 \mathrm{~min}$, as it was in previous studies $[6,7]$. Prolongation of hypoglycaemia seems to augment counterregulatory hormone responses and at the same time deteriorate cognitive function less [35, 36]. These changes are similar to those observed in our study in slow-fall as compared to fast-fall hypoglycaemia. Whether the effects of fast-fall versus slow-fall hypoglycaemia are direct (i.e. due to rate of decreasing blood glucose concentrations "per se") or, at least in part indirect (i.e. mediated also by different duration of hypoglycaemia) can not be established from our data.

However, a direct effect of the fast fall of blood glucose on glucose sensing cells, either in the brain [37] or liver (portal vein) [38], has been observed. For example, in dogs hepatic glucosensors seem to play a greater role in hypoglycaemic counterregulation in the presence of slow-fall as compared to fast-fall of blood glucose concentrations [39]. In contrast to the effect on adrenaline responses, the slow-fall study did not result in greater activation of the peripheral sympathetic nervous system as indicated by plasma noradrenaline concentrations, as well as by rates of noradrenaline spillover. Spillover rates and plasma noradrenaline concentrations were greater in the fast-fall than in the slow-fall study, although only the spillover rates reached statistical significance. However, because in the postprandial state, the plasma noradrenaline clearance increases [40], the plasma noradrena- line concentrations underestimate the activation of the peripheral sympathetic nervous system. The differential effects of the rate of decreasing blood glucose on adreno-medullary responses (enhancement of adrenaline responses by slow fall of blood glucose) and peripheral sympathetic nerve ending responses (enhancement of noradrenaline spillover by a fast fall of blood glucose), are not easy to explain. In rats, rapid, not slow-fall blood glucose activates the peripheral sympathetic nervous system [42]. The postprandial state itself activates peripheral sympathetic nerve responses, but not adrenomedullary adrenaline responses as shown in the euglycaemia experiments (Fig. 3), and as previously observed [41]. It is possible that in the postprandial state the peripheral sympathetic nerves respond more than adrenomedullary adrenaline to subtle stimuli such as greater rate of decreasing blood glucose. An additional possible explanation might be the differences in morpho-physiological architecture of the two peripheral effectors. It is well known that the activation of the peripheral sympathetic nervous system responds to stimuli different from those of the adrenal medulla, such as activation of baroceptors [42]. The measured peripheral vascular resistances were similar in the fast-fall and slow-fall studies, but one can not exclude differences in splanchnic area.

The rate of decreasing blood glucose did not affect the emergence of symptoms of hypoglycaemia in the postprandial state in accordance with previous studies in the fasting state $[4,5,6,7]$. However, because in the postprandial state the responses of adrenaline were greater in the slow-fall study, one would expect that autonomic symptoms were also greater. The reasons why this was not the case in our study are not clear, but might include, the role of activation of peripheral sympathetic nervous system in addition to secreted adrenaline; the postprandial condition that might reduce the score of hypoglycaemic symptoms as compared to the fasting condition, both in the slow-fall and fast-fall study.

We used a battery of cognitive function tests which are sensitive to hypoglycaemia [20,21], to explore the aspects of cognitive function that are required for coping with common tasks in everyday life (e.g., driving). The results indicate that the performance of all these tests deteriorated during the postprandial hypoglycaemia compared to the euglycaemia control study. This suggests that these tests are useful for investigating cognitive performance not only during hypoglycaemia in the fasting state $[20,21]$, but also during hypoglycaemia in the postprandial condition. The results of the individual tests generally showed a greater degree of deterioration in the fast-fall than in the slow-fall study, although this was statistically significant only in four out of the seven tests administered (Table 5). The performance of the most demanding and complex tests (Trail-Making B, PASAT 2 s, Digit Vigilance 
Test and Verbal Memory Test) showed greater deterioration in the fast-fall than in the slow-fall study. On the Trail-Making test, part B showed a greater deterioration in cognitive performance in the fast-fall study. Although the test assesses mental flexibility and visuomotor tracking in both parts A and B [20], part B demands greater attention to switch quickly from numbers to letters. Similarly, performance on the PASAT, which measures information processing efficiency and sustained attention, deteriorated more in the fast-fall study when the trial was administered with numbers presented at 2-s intervals rather than at 4-s intervals. Clearly, the shorter presentation rate in the PASAT ( 2 s.) makes more demands on attention. Similarly, the Digit Vigilance Test, which assesses the ability to sustain attention over a period of time as well as visual scanning, also deteriorated to a greater extent in the fast-fall study. Therefore, it seems that attention-demanding tasks, in particular those requiring sustained attention, are more sensitive to a fast-fall of blood glucose. In contrast, the Digit Span Backward, which is a more complex span test than the Digit Span Forward (which we did not include in our battery because its sensitivity to hypoglycaemia has produced variable results in previous studies [20]) showed similar deterioration during hypoglycaemia independent of the rate of decreasing blood glucose concentrations. This test measures more than simple attention functions and correlates with general intelligence. Because it requires storing a few digit and spelling digit sequences backwards it also requires working memory. Finally, the Verbal Memory Test (short-memory and simple attention) deteriorated more in the fast-fall study.

The responses to hypoglycaemia were re-examined after recovery of plasma glucose to normal values. In contrast to responses of counterregulatory hormones and symptoms which normalised, cognitive performance was still impaired compared to the baseline with no differences between the slow-fall and the fast-fall study. Five out of the seven tasks (the Trail Making par A and B, Pasat 4 s. and 2 s., and Verbal Memory Test) were deteriorated after recovery from hypoglycaemia, whereas cognitive performance on Digit Span Backward and Digit Vigilance Test tended to normalise.

The finding that recovery of cognitive function is delayed after restoring euglycaemia is not new [43], but our studies indicate that such a finding extends to the postprandial state. Although the reason why some tasks showed a deterioration in the recovery phase whereas other tasks normalised is not clear, this finding suggests that hypoglycaemia (neuroglycopenia) had a more prolonged effect on some aspects of cognitive function than others. The causes of this delayed recovery of cognitive functioning after recovery from hypoglycaemia are also not known. It is likely that several factors, such as fatigue and stress, could play a role. However, we found that duration of diabetes highly correlated with performance of the Trail Making Test, whereas $\mathrm{HbA}_{1 \mathrm{c}}$ and plasma concentrations of pancreatic polypeptide predicted best the performance on PASAT and the Verbal Memory Test.

In conclusion, our studies indicate that when hypoglycaemia occurs in the postprandial condition and sitting position, a fast-fall of blood glucose is potentially more dangerous than a slow-fall because cognitive function is more impaired and the responses of the key counterregulatory hormone adrenaline and symptoms are not potentiated. These findings suggest the importance of preventing episodes of postprandial hypoglycaemia that might prospectively increase with the more and more popular use of rapid-acting insulin analogues at meal-time $[1,44]$.

A potentially important finding showing that subjects with Type 1 diabetes who generally lack glucagon responses to hypoglycaemia in the fasting state, do respond with glucagon secretion to postprandial hypoglycaemia, deserves further investigation.

Acknowledgements. The authors would like to thank G. Cipiciani, D. Mughetti and R. Pippi for their expert laboratory assistance. The authors are grateful to the Juvenile Diabetes Reasearch Foundation International for financial support (grant 1-2001-102).

\section{References}

1. Bolli GB, Di Marchi RD, Park GD, Pramming S, Koivisto VA (1999) Insulin analogueues and their potential in the management of diabetes mellitus. Diabetologia 42:1151-1167

2. Attia N, Jones TW, Holcombe J, Tamborlane WV (1998) Comparison of human regular and lispro insulins after interruption of continuous subcutaneous insulin infusion and in the treatment of acutely decompensated IDDM. Diabetes Care 21:817-821

3. Guerci B, Meyer L, Salle A et al. (1991) Comparison of metabolic deterioration between insulin analogue and regular insulin after a 5-hour interruption of a continuous subcutaneous insulin infusion in type 1 diabetic patients. J Clin Endocrinol Metab 84:2673-2678

4. Lilavivathana U, Brodows RG, Woolf PD, Campbell RG (1979) Counterregulatory hormonal responses to rapid glucose lowering in diabetic man. Diabetes 28:873-877

5. Santiago JV, Clarke WL, Shah SD, Cryer PE (1980) Epinephrine, norepinephrine, glucagon, and growth hormone release in association with physiological decrements in the plasma glucose concentration in normal and diabetic man. J Clin Endocrinol Metab 51:877-883

6. Amiel SA, Simonson DC, Tamborlane WV, DeFronzo RA, Sherwin RS (1987) Rate of glucose fall does not affect counterregulatory hormone responses to hypoglycaemia in normal and diabetic humans. Diabetes 36:518-522

7. Mitrakou A, Mokan M, Ryan C, Veneman T, Cryer P, Gerich J (1993) Influence of plasma glucose rate of decrease on hierarchy of responses to hypoglycaemia. J Clin Endocrinol Metab 76:462-465

8. Evans ML, Pernet A, Lomas J, Jones J, Amiel SA (2000) Delay in onset of awareness of acute hypoglycaemia and of restoration of cognitive performance during recovery. Diabetes Care 23:893-897 
9. Torlone E, Fanelli C, Rambotti AM et al. (1994) Parmacokinetics, pharmacodynamics and glucose counterregulation following subcutaneous injection of the monomeric insulin analogueue [Lys(B28),Pro(B29)] in IDDM. Diabetologia 37:713-720

10. Lalli C, Ciofetta M, Del Sindaco P et al. (1999) Long-term intensive treatment of Type 1 diabetes with the short-acting insulin analogueue lispro in variable combination with NPH insulin at mealtime. Diabetes Care 22:468-477

11. Hirsch IB, Heller SR, Cryer PE (1991) Increased symptoms of hypoglycaemia in the standing position in insulindependent diabetes mellitus. Clin Sci (Colch) 80:583-586

12. Robinson AM, Parkin HM, Macdonald IA, Tattersall RB (1994) Physiological responses to postural change during mild hypoglycaemia in patients with IDDM. Diabetologia 37:1241-1250

13. Ewing DJ, Clarke BF (1986) Autonomic neuropathy: its diagnosis and prognosis. Clin Endocrinol Metab 15:855-888

14. Fanelli CG, Epifano L, Rambotti AM et al. (1993) Meticulous prevention of hypoglycaemia normalizes the glycemic thresholds and magnitude of most of neuroendocrine responses to, symptoms of, and cognitive function during hypoglycaemia in intensively treated patients with shortterm IDDM. Diabetes 42:1683-1689

15. McGuire E, Helderman J, Tobin J, Andres R, Berman M (1976) Effects of arterial venous sampling on analysis of glucose kinetics in man. J Appl Physiol 41:565-573

16. De Feo P, Perriello G, Ventura MM et al. (1986) Studies on overnight insulin requirements and metabolic clearance rate of insulin in normal and diabetic man: relevance to the pathogenesis of the dawn phenomenon. Diabetologia 29:475-480

17. Marker JC, Cryer PE, Clutter WE (1994) Simplified measurement of norepinephrine kinetics: application to studies of aging and exercise training. Am J Physiol 267:E380E387

18. Paramore DS, Fanelli CG, Shah SD, Cryer PE (1998) Forearm norepinephrine spillover during standing, hyperinsulinemia, and hypoglycaemia. Am J Physiol 275:E872-E881

19. Paramore DS, Fanelli CG, Shah SD, Cryer PE (1999) Hypoglycaemia per se stimulates sympathetic neural as well as adrenomedullary activity, but, unlike the adrenomedullary response, the forearm sympathetic neural response is not reduced after recent hypoglycaemia. Diabetes 48:1429-1436

20. Mitrakou A, Ryan C, Veneman T et al. (1991) Hierarchy of glycemic thresholds for counterregulatory hormone secretion, symptoms, and cerebral dysfunction. Am J Physiol 260:E67-E74

21. Lezak MD (1995) Neuropsychological assessment. Oxford University Press, New York/Oxford, pp 154-156

22. Gronwall DMA (1977) Paced auditory serial-addition task: a measure of recovery from concussion. Percept Mot Skills 44:367-373

23. Fanelli CG, De Feo P, Porcellati F et al. (1992) Adrenergic mechanisms contribute to the late phase of hypoglycaemic glucose counterregulation in humans by stimulating lipolysis. J Clin Invest 89:2005-2013

24. Kohn A, Annibale B, Suriano G, Severi C, Spinella S, Delle Fave G (1985) Gastric acid and pancreatic polypeptide responses to modified sham feeding: indication of an increased basal vagal tone in a subgroup of duodenal ulcer patients. Gut 26:776-782

25. Kuzuya H, Blix PN, Horowitz DL, Steiner DF, Rubenstein AH (1977) Determination of free and total insulin and C-peptide in insulin treated diabetics. Diabetes 26:22-29
26. Winer BJ, Brown DR, Michels KM (1991) Statistical principles in experimental design 3rd edn. McGraw Hill, New York, pp 497-572

27. Holland BS, Copenhaver M (1988) Improved Bonferronitype multiple testing procedures. Psychol Bull 104:145-148

28. Zar JH (1984) Biostatistical Analysis. Prentice Hall, Englewood Cliffs, pp 151-162

29. Fanelli C, Calderone S, Epifano L et al. (1993) Demonstration of a critical role for free fatty acids in mediating counterregulatory stimulation of gluconeogenesis and suppression of glucose utilization in humans. J Clin Invest 92:1617-1622

30. Gerich JE, Langlois M, Noacco C, Karam JH, Forsham PH (1973) Lack of glucagon response to hypoglycaemia in diabetes: evidence for an intrinsic pancreatic alpha cell defect. Science 182:171-173

31. Cryer PE (1994) Banting lecture. Hypoglycaemia: the limiting factor in the management of IDDM. Diabetes 43:1378-1389

32. Liu DT, Adamson UC, Lins PE, Kollind ME, Moberg EA, Andreasson K (1992) Inhibitory effect of circulating insulin on glucagon secretion during hypoglycaemia in type I diabetic patients. Diabetes Care 15:59-65

33. Burge MR, Castillo KR, Schade DS (1997) Meal composition is a determinant of lispro-induced hypoglycaemia in IDDM. Diabetes Care 20:152-155

34. Strachan MW, Frier BM (1997) Early postprandial hypoglycaemia following administration of lispro insulin. Diabetes Care 20:1214-1215

35. Kerr D, Macdonald IA, Tattersall RB (1989) Adaptation to mild hypoglycaemia in normal subjects despite sustained increases in counter-regulatory hormones. Diabetologia 32:249-254

36. Kerr D, Macdonald IA, Tattersall RB (1991) Patients with type 1 diabetes adapt acutely to sustained mild hypoglycaemia. Diabet Med 8:123-128

37. Borg WP, Sherwin RS, During MJ, Borg MA, Shulman GI (1995) Local ventromedial hypothalamus glucopenia triggers counterregulatory hormone release. Diabetes 44:180-184

38. Donovan CM, Halter JB, Bergman RN (1991) Importance of hepatic glucoreceptors in sympathoadrenal response to hypoglycaemia. Diabetes 40:155-158

39. Donovan CM, Hamilton-Wessler M, Halter JB, Bergman RN (1993) Primacy of liver glucosensors in the sympathetic response to progressive hypoglycaemia. Proc Natl Acad Sci USA 91:2863-2867

40. Vaz M, Cox HS, Kaye DM, Turner AG, Jennings GL, Esler MD (1995) Fallibility of plasma noradrenaline measurements in studying postprandial sympathetic nervous responses. J Auton Nerv Syst 56:97-104

41. Patel JN, Eisenhofer G, Coppack SW, Miles JM (1999) Norepinephrine spillover in forearm and subcutaneous adipose tissue before and after eating. J Clin Endocrinol Metab 84:2815-2819

42. Young JB, Landsberg L (1998) Catecholamines and the adrenal medulla. In: Wilson JD et al. (eds) Williams textbook of endocrinology 9th edn. W.B. Saunders, Philadelphia, pp 665-728

43. Gold AE, MacLeod KM, Deary IJ, Frier BM (1995). Hypoglycaemia-induced cognitive dysfunction in diabetes mellitus: effect of hypoglycaemia unawareness. Physiol Behav 58:501-511

44. Torlone E, Pampanelli S, Lalli C et al. (1996) Effects of the short-acting insulin analogue [Lys(B28), Pro(B29)] on postprandial blood glucose control in IDDM. Diabetes Care 19:945-952 